\section{DIGITAL COMMONS \\ @ UNIVERSITY OF SOUTH FLORIDA}

\section{Revista Surco Sur}

Volume 8 | Issue 11

Article 20

6-30-2018

\title{
Silvina Ocampo: “Poemas Breves”, de Poesía inédita y dispersa
}

Katherine Brown

Follow this and additional works at: https://digitalcommons.usf.edu/surcosur

\section{Recommended Citation}

Brown, Katherine. 2018. Silvina Ocampo: "Poemas Breves”, de Poesía inédita y dispersa. Revista Surco Sur, Vol. 8: Iss. 11, 66-71.

DOI: http://dx.doi.org/10.5038/2157-5231.8.11.18

Available at: https://digitalcommons.usf.edu/surcosur/vol8/iss11/20

This LA ESQUINA DEL TRADUCTOR is brought to you for free and open access by the Open Access Journals at Digital Commons @ University of South Florida. It has been accepted for inclusion in Revista Surco Sur by an authorized editor of Digital Commons @ University of South Florida. For more information, please contact digitalcommons@usf.edu. 


\section{Katherine Brown (Introducción y traducción)}

\section{Si I vi na Ocampo: "PoemasBreves", dePoeś a i nédi ta y di spersa}

La figura de Silvina Ocampo (1903-1993, Buenos Aires) y sus obras o se consideran periféricas o centrales, dependiendo del contexto desde el que se le analice. Su hermana, Victoria Ocampo, editaba y publicaba la revista Sur, la cual dio a conocer los primeros cuentos y poemas de Silvina. Junto con su esposo, Adolfo Bioy Casares, y Jorge Luis Borges, publica en 1940 la A ntología de literatura fantástica, contribuyendo a que se fomentara más en la región. Es decir, entre su círculo literario y social, era una figura central. Pero, en los anales de la historia poco se le reconoce fuera del Cono Sur, y se ha vuelto una figura periférica en los estudios literarios y culturales. Según el crítico Melvin Arrington, esto puede ser porque no existen tantas traducciones al inglés de ella como de otros escritores latinoamericanos. ${ }^{1}$

Los "Poemas breves" traducidos aquí aparecieron por primera vez en la colección de Poesía inédita y dispersa (2001, Emecé), pero fueron escritos entre 1960 y 1990. Se nota una voz poética ya mayor, pero juguetona, considerando las paradojas del mundo, reflejando sobre la vida, aconsejando y advirtiendo, mientras debajo siempre fluye alguna ironía. Los poemas en sí son muestras exitosas de una meta poética principal: economizar la palabra y maximizar el efecto emotivo. Algunos se leen como axiomas o refranes, otros son casi haiku estilizados.

Uno en particular, "Dibujos", fue el que me inspiró a

traducir la colección entera, por su sencilla profundidad, o su profunda sencillez. La traducción produjo una aliteración nueva (con la s en vez de las vocales), que funciona en inglés, y es ejemplo de las retóricas nuevas que se pueden producir en una traducción. En la mayoría de los casos, me preocupé más por el espíritu del poema que de la métrica; muchos carecen de una métrica fija, pero traté de, más o menos, imitar el conteo silábico. Lo más importante para mí era conservar el tono, la ironía, el lenguaje economizado. Más allá de la estructura, quería que las traducciones mantuvieran la calidad de reflexión, de hacer al lector sonreír a sí mismo y ser cómplice con ella en reconocer las ironías, contradicciones e inutilidades del mundo en que vivimos.

${ }^{1}$ Arrington, M elvin S., Jr. "Silvina Ocampo". Spanish A merican Women Writers: A bio-Biographical Source Book. Ed. Diane E. Marting. Greenwood: Westport, CT, 1990. 


\section{"PoemasBreves"}

\section{La esfinge}

El ser más inesperado es uno mismo:

hasta las esfinges nos miran con ojos asombrados.

\section{Rubor}

Existe una tristeza

de estar triste y también

existe una vergüenza

cruel de tener vergüenza.

\section{Dibujos}

Junto al agua, los grillos

con su canto dibujan

formas de las estrellas.

\section{Sacrificios puros}

Le basta a la mentira, la mentira.

¡Pero cuántas mentiras la verdad necesita para que la comprendan!

\section{Celos y vanidad}

Toda audacia de la timidez despierta la envidia de los vanidosos como toda conquista o belleza de un muerto despierta el odio de los celosos.

\section{Contradicción}

Por no querer sufrir sufrí muchísimo.

Por no buscar la dicha fui feliz.

Lo único que sabemos

Única Sabiduría

es lo que nos sorprende:

que todo pasa, como

si no hubiera pasado.

\section{Perpetuidad}

¡Qué hermafrodita es el remordimiento!

\section{Dilección}

Con preferencia siempre recordamos los queridos defectos de la dicha; recordamos también con preferencia de una persona amada los pecados.

\section{Cuadro apócrifo}

La santa se convierte en prostituta; el león, el mono, el ángel, el pez en un jardín; cuatro niños que juegan a la mancha, en una playa. Con las vicisitudes del tiempo o casualmente aparece en la tela de cuadro otra pintura que fue la original icomo nuestros recuerdos!

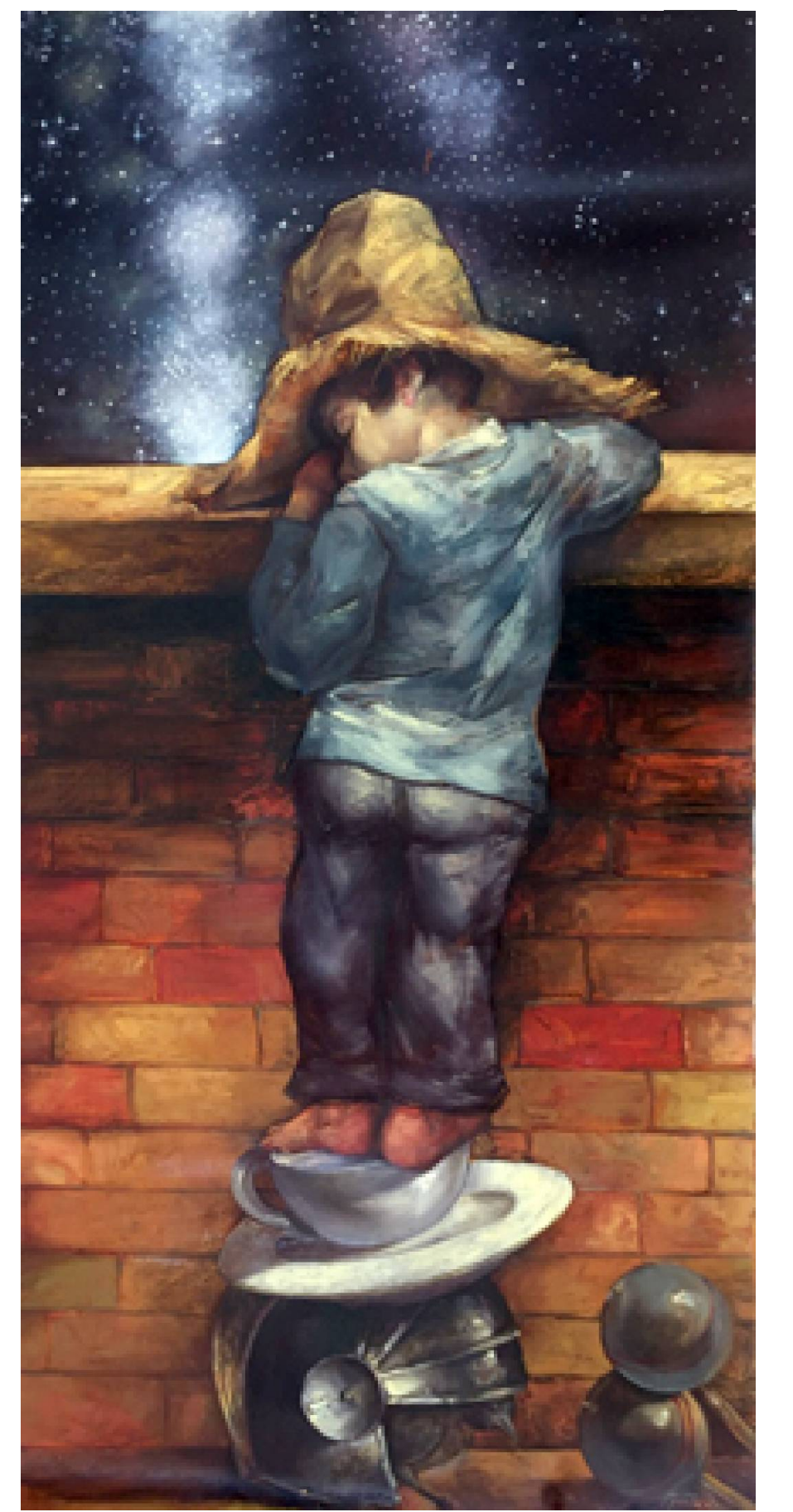

obra de Alexis Pantoja 


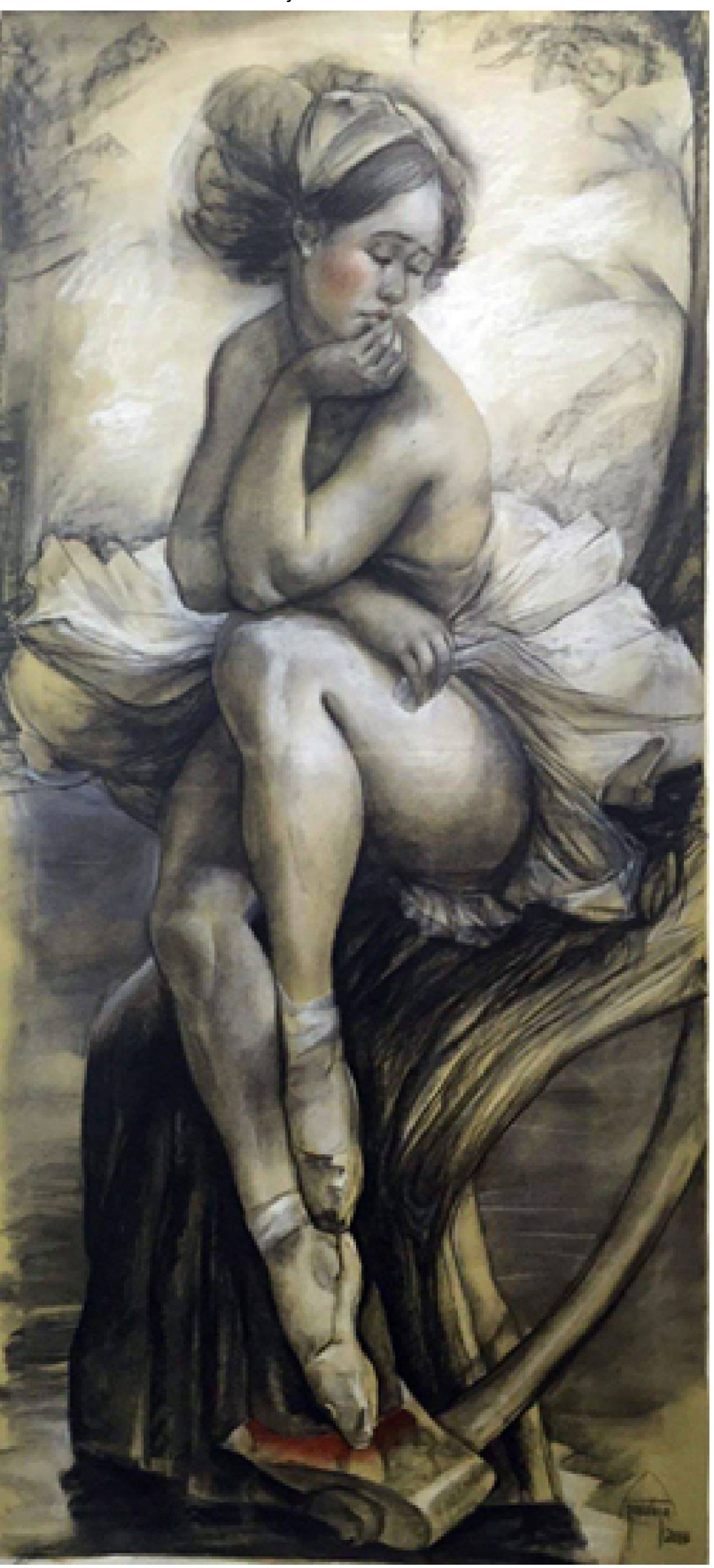

\section{Consecuencias}

A mamos en un ser

a todos los demás

cuando ese ser nos ama.

Odiamos en un ser

a todos los demás

si ese ser no nos ama.

\section{Vanidad de vanidades}

Vivimos para una casa que no podremos construir, para un viaje que no haremos

y para un libro que nunca

llegaremos a escribir;

como un dibujo trazado

en una hoja cuyos límites

exiguos no han permitido

la inclusión total de un plano.

\section{Nocturno}

Sueñan las casas que son barcos cuando de noche hay viento, oscuridad y Iluvia.

\section{Estado de gracia}

Con qué bondad nos escuchaba Dios

cuando aún no sabíamos hablar.

\section{Inocencia}

Conocí la lujuria dentro de un catecismo

blanco de mi primera

comunión, con la pura

prematura lujuria.

\section{Imitaciones}

Nunca el zorzal cantó su canto definitivo porque canta solo

el canto de los otros pájaros:

él no lo sabe y cree que inventa

siempre la misma melodía,

que otro pájaro siempre imita.

El agua

El agua de la lluvia

y el agua del arroyo

no son tan persistentes

como ella cuando llora.

\section{A premio}

Nuestra impaciencia por morir proviene de tener que morir sin remisión.

\section{Perplejidad}

Por qué si me arrodillo

rezando, siempre pienso:

"Qué hacen mis pies, ahora". 
Algunas veces en nuestra tristeza

estar desesperados nos consuela.

\section{Soledad}

En algunas personas

amamos a personas

que no existen ya;

en otras, amamos a nadie,

ni a esa misma persona.

\section{"Short Poems"}

\section{The Sphinx}

The one most unexpected is oneself:

even the sphinxes eye us with amazement.

\section{Blush}

There exists a sorrow

from being sad, and also

there exists a cruel shame

from being ashamed.

Drawings

Beside the water, the songs

of crickets sketch

the shapes of stars

\section{Pure Sacrifices}

For the lie, the lie is enough.

But how many lies the truth needs

to be understood!

All the audacity of timidity

\section{Jealousy and Vanity}

awakens the envy of the vain

as all conquest or beauty of the dead

awakens the hatred of the jealous.

\section{Contradiction}

For not wanting to suffer, I suffered a great deal By not seeking happiness I was happy.

\section{One Wisdom}

The only thing we know

is what surprises us:

that everything happens, as

if it had never happened.

\section{Perpetuity}

Remorse is such a hermaphrodite! 

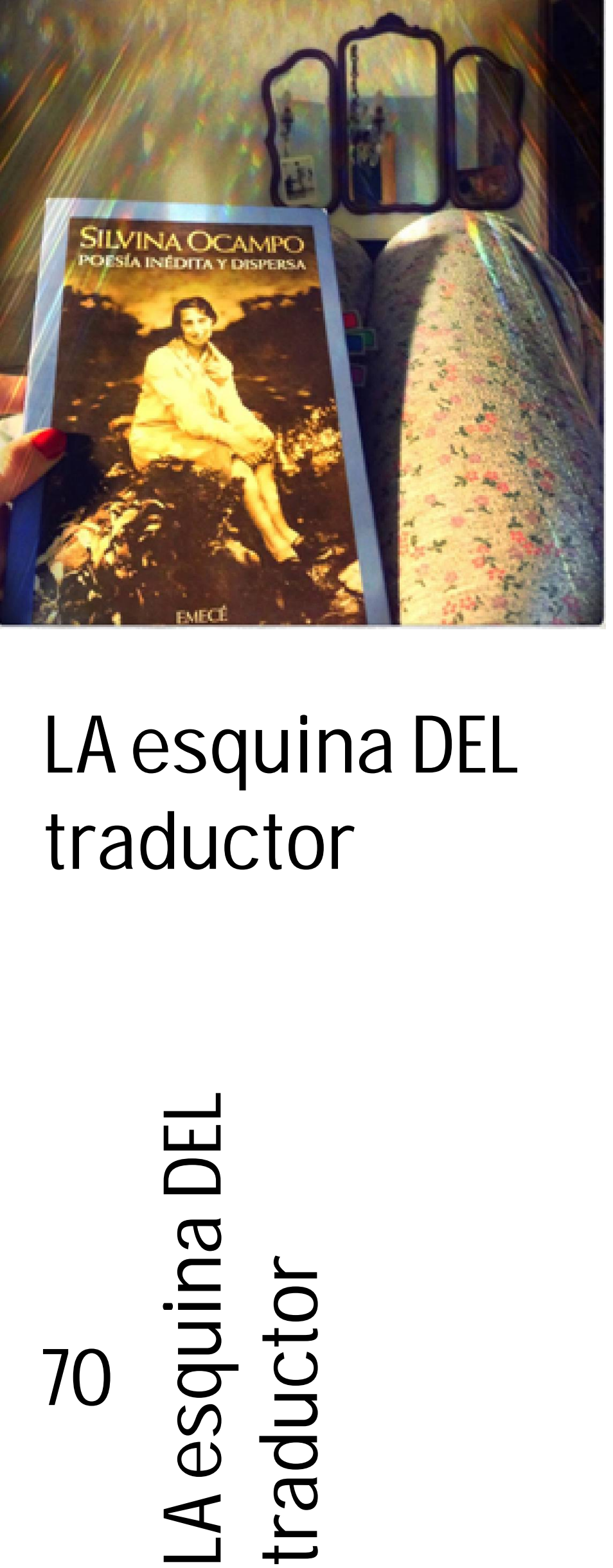

\section{Affection}

With prodivity we always remember the precious flaws of bliss; we also remember with proclivity of someone beloved, the sins.

\section{Apocryphal Painting}

The saint becomes a prostitute; the lion, the monkey, the angel, the fish - a garden; four kids playing tag - a beach.

With the vicissitudes of time or by chance another painting that was the original appears on the canvas, like our memories!

\section{Consequences}

We love in a person

all other people

when that person loves us.

we hate in a person

all other people

if that person doesn't love us.

\section{Vanity of Vanities}

We live for a house we won't be able to build, for a trip we won't take and for a book that we never will come to write; like a drawing traced on a sheet whose meager limits have not allowed for the complete inclusion of a plan.

\section{Nocturne}

Houses dream they are boats at night when there is wind, darkness and rain.

\section{State of Grace}

With what kindness did God listen to us when we didn't yet know how to speak.

I met lechery

\section{Innocence}

inside a white

Catechism from my First

Communion, with pure

premature lechery.

\section{Imitations}

The thrush never sang its definitive because it sings

the song of other birds:

he doesn't know it and thinks that he al ways invents the same melody that another bird always imitates. 


\section{Water}

Rainwater

and creekwater

aren't as persistent

as she when she cries.

\section{Urgency}

Our impatience to die comes from having to die without absolution.

\section{Perplexity}

Why, if I kneel down

praying, do I always think:

"Now what are my feet doing."

\section{Desperation}

Sometimes in our sorrow desperation consoles us.

\section{Solitude}

In some people

we love people

who no longer exist;

in others, we love no one, not even that very person.
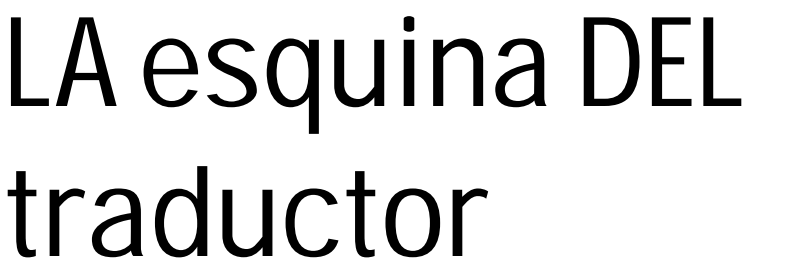

obra de Alexis Pantoja

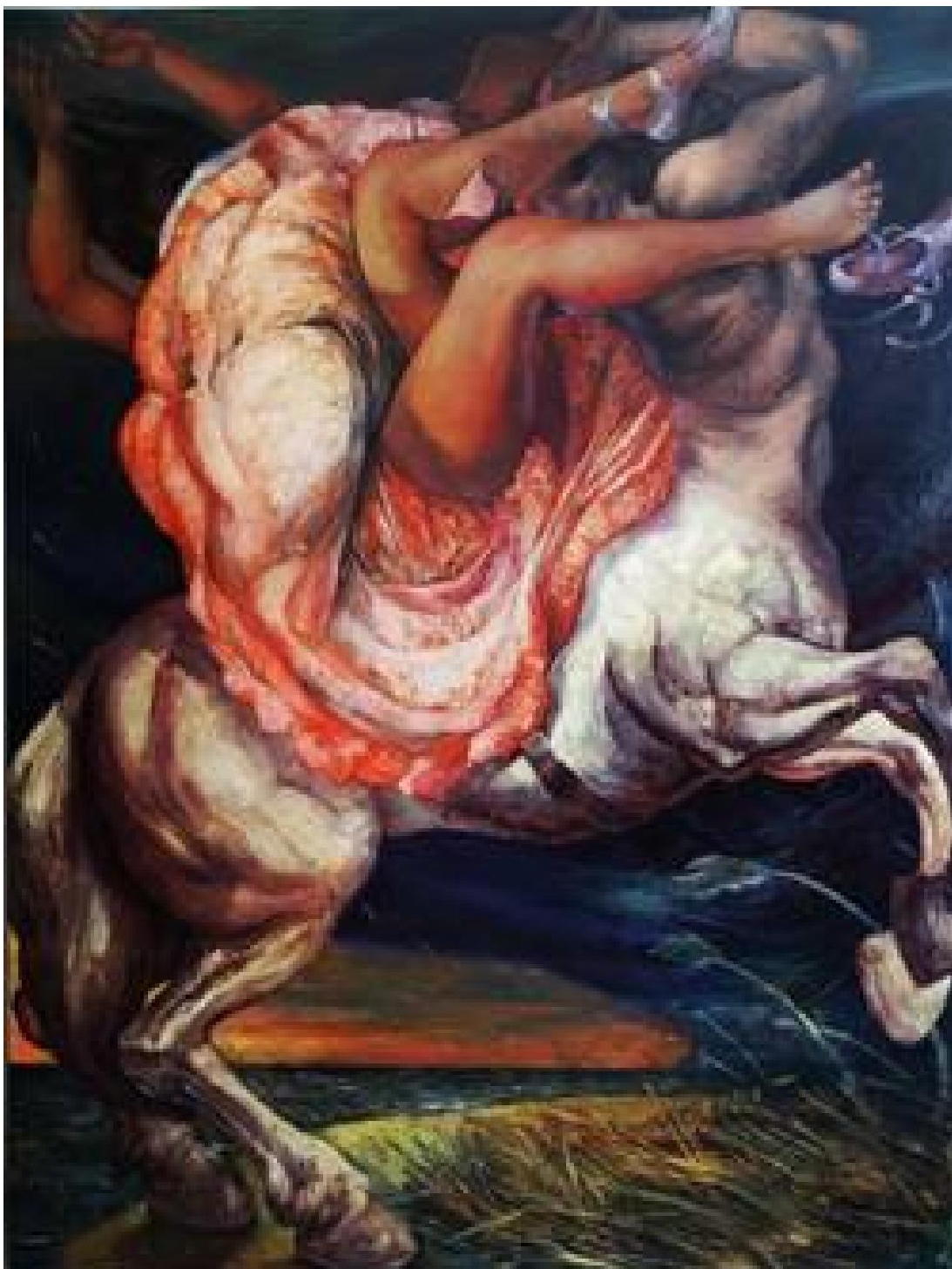

